УДК 541.122: 538.214

\title{
Modeling EPR Powder Spectra of triclinic $\mathrm{BiNb}_{1-x} \mathrm{Mn}_{x} \mathrm{O}_{4-\delta}$
}

Vladimir P. Lutoev*

Institute of Geology of Komi Scientific Center UB RAS

Pervomayskaya 54, Syktyvkar, 167982

Russia

Nadezhda A. Zhuk ${ }^{\dagger}$

Pitirim Sorokin Syktyvkar State University Oktyabrskiy, 55, Syktyvkar, 167001

Russia

Boris A. Makeev $\ddagger$

Institute of Geology, Komi Scientific Center UB RAS Pervomayskaya, 54, Syktyvkar, 167982

Russia

Vladimir A. Belyy ${ }^{\S}$

Institute of Chemistry, Komi Scientific Center UB RAS

Pervomayskaya, 48, Syktyvkar, 167982

Russia

Dmitriy S. Beznosikov

Pitirim Sorokin Syktyvkar State University

Oktyabrskiy, 55, 167001

Syktyvkar, 167001

Russia

Received 10.05.2017, received in revised form 10.03.2018, accepted 20.06.2018

EPR of solid solutions $\mathrm{BiNb}_{1-x} \mathrm{Mn}_{x} \mathrm{O}_{4-\delta}$ in triclinic modification have been studied. The EPR spectra revealed sextet structure of $M n(I I)$ ions with $8.4 \mathrm{mT}$ splitting and some features at $g=3.80$ and 1.47 , and a broad diffuse band with $g \approx 2.2$ having a sextet with $8 \div 9 \mathrm{mT}$ splitting and $g=2.0$ against its background. The modeling has shown that the best reproduction of the components of the spectrum of triclinic $B i N b_{1-x} M_{n} O_{4-\delta}$ is observed with the following parameters: $g=2.0, D=1580 \cdot 10^{-4} \mathrm{~cm}^{-1}$, $E=495 \cdot 10^{-4} \mathrm{~cm}^{-1}, \Delta D / D=\Delta E / E=0.08, A=8.4 \mathrm{mT}$, Lorentzian shape of the individual line with $\Delta B_{p p}=2.5 \mathcal{M T}$

Keywords: EPR, modeling, $\mathrm{BiNbO}_{4}$, functional ceramics.

DOI: 10.17516/1997-1397-2018-11-5-615-621.

Emerging interest to bismuth niobate $\mathrm{BiNbO}_{4}$ and solid solutions is associated with the discovery of its antiferroelectric [1], catalytic [2] and microwave dielectric properties [3]. Materials based on bismuth orthoniobate solid solutions are used as dielectric layers in monolithic capacitors made up of alternating thin layers of a ceramic dielectric and fusible electric conductors. They are also applied in SHF devices [4].

\footnotetext{
*vlutoev@geo.komisc.ru

${ }^{\dagger}$ nzhuck@mail.ru

${ }^{\ddagger}$ makboris@mail.ru

§skeyling@yandex.ru

ฯuvn71p3@gmail.com
}

(c) Siberian Federal University. All rights reserved 
In this paper, the results of the EPR study of solid solutions of triclinic $\mathrm{BiNb}_{1-x} \mathrm{Mn}_{x} \mathrm{O}_{4-\delta}$ are presented, the results of theoretical modeling of spectra are shown.

The high-temperature modification of bismuth orthoniobate was first mentioned in the $\mathrm{Au}-$ rivillius's work [5], where the $\beta-\mathrm{BiNbO}_{4}$ crystal structure was indexed in triclinic syngony with the unit cell parameters of $a=0.771 \mathrm{~nm}, b=0.555 \mathrm{~nm}, c=0.797 \mathrm{~nm}, \alpha=89^{\circ}, \beta=77^{\circ}, \gamma=87^{\circ}$ (P-1). The coordination polyhedron of niobium atoms in $\beta-\mathrm{BiNbO}_{4}$ is an octahedron $\left(\mathrm{NbO}_{6}\right)$, which is more distorted comparing with that in the $\alpha$-form $\mathrm{BiNbO}_{4}$. Its Nb-O bond lengths are nonequivalent and vary from 0.181 to $0.230 \mathrm{~nm}$. In the unit cell volume, four bismuth atoms are located in the hollow sites formed by niobium-oxygen octahedra joined by equatorial vertexes.

\section{Experimental}

The solid solution samples were obtained via the standard ceramic procedure from "special pure" grade $\mathrm{Bi}(\mathrm{III}), \mathrm{Nb}(\mathrm{V})$, and $\mathrm{Mn}(\mathrm{III})$ oxides using staged calcination at $650^{\circ} \mathrm{C}, 950^{\circ} \mathrm{C}$ and $1100^{\circ} \mathrm{C}$. Phase composition of the samples was monitored by means of scanning electron microscopy (electron scanning microscope Tescan VEGA 3LMN, energy dispersion spectrometer INCA Energy 450) and X-ray phase analysis (a DRON-4-13 diffractometer, $\mathrm{CuK} \alpha$ emission). The unit cell parameters of the solid solutions were calculated using the CSD program package [6]. The quantitative measurement of iron in the solid solution samples was performed by atom-emission spectrometry (a SPECTRO CIROS ISP spectrometer).

EPR spectra of the polycrystalline samples of bismuth orthoniobate manganese-containing solid solutions were recorded using a RadioPAN SE/X 2547 X-band radiospectrometer (Center for Collective Usage "Geonauka", Komi Scientific Center, Ural Branch, Russian Academy of Sciences). The spectra were recorded using a rectangular resonator (RX102, TE 102 mode) at room temperature as the first derivative at the HF modulation frequency of $100 \mathrm{MHz}$ with the amplitude of $0.25 \mathrm{mT}$ and the SHF field power of $35 \mathrm{~mW}$. A batch of a sample $(\sim 100 \mathrm{mg})$ was put into a quartz tube (external diameter of $4 \mathrm{~mm}$ ). The EPR signal of a miniature reference sample (anthracite, singlet line $\mathrm{g}_{0}=2.0032, \Delta \mathrm{B}_{p p}=0.5 \mathrm{mT}$ ) was used to calibrate the amplification of the apparatus. The quartz ampoule with the reference sample was rigidly fixed in the resonator coaxially to the test tube with the measured sample. For each sample, the spectrum in the magnetic field range of $0 \div 700 \mathrm{mT}$ and the lines of the reference were separately recorded with the scan step of $5 \mathrm{mT}$. The total spectra were normalized to the reference line intensity and then to $100 \mathrm{mg}$ of the sample.

\section{Results and discussion}

The manganese-containing $\mathrm{BiNbO}_{4}$ solid solutions were obtained at $x \leqslant 0.06$. The X-ray phase analysis proved that the obtained preparations were single-phase (Figs. 1, 2). The unit cell parameters of the diluted solid solutions were practically unchanged and close to those of triclinic modification bismuth orthoniobate: $a=0.7604 \mathrm{~nm}, b=0.5536 \mathrm{~nm}, c=0.7929 \mathrm{~nm}$, $\alpha=90.05^{\circ}, \beta=77.41^{\circ}, \gamma=87.17^{\circ}(x=0.005)$ and $a=0.7605 \mathrm{~nm}, b=0.5537 \mathrm{~nm}, c=0.7925$ $\mathrm{nm}, \alpha=90.13^{\circ}, \beta=77.46^{\circ}, \gamma=87.23^{\circ}(x=0.06)$.

The EPR spectra of the $\mathrm{BiNb}_{1-x} \mathrm{Mn}_{x} \mathrm{O}_{4-\delta}$ solid solutions $(0.02 \leqslant x \leqslant 0.06)$ contain a wellresolved sextet structure with $8.4 \mathrm{mT}$ splitting with g-factor of 3.80 and a broad diffuse band with $\Delta B_{p p} \sim 110 \mathrm{mT}$ centered at $g \sim 2.2$, which manifests the sextet with $8 \div 9 \mathrm{mT}$ splitting and $g=2.0$ (Fig. 2.). The integrated intensity of the band with $g=3.80$ was almost constant and 


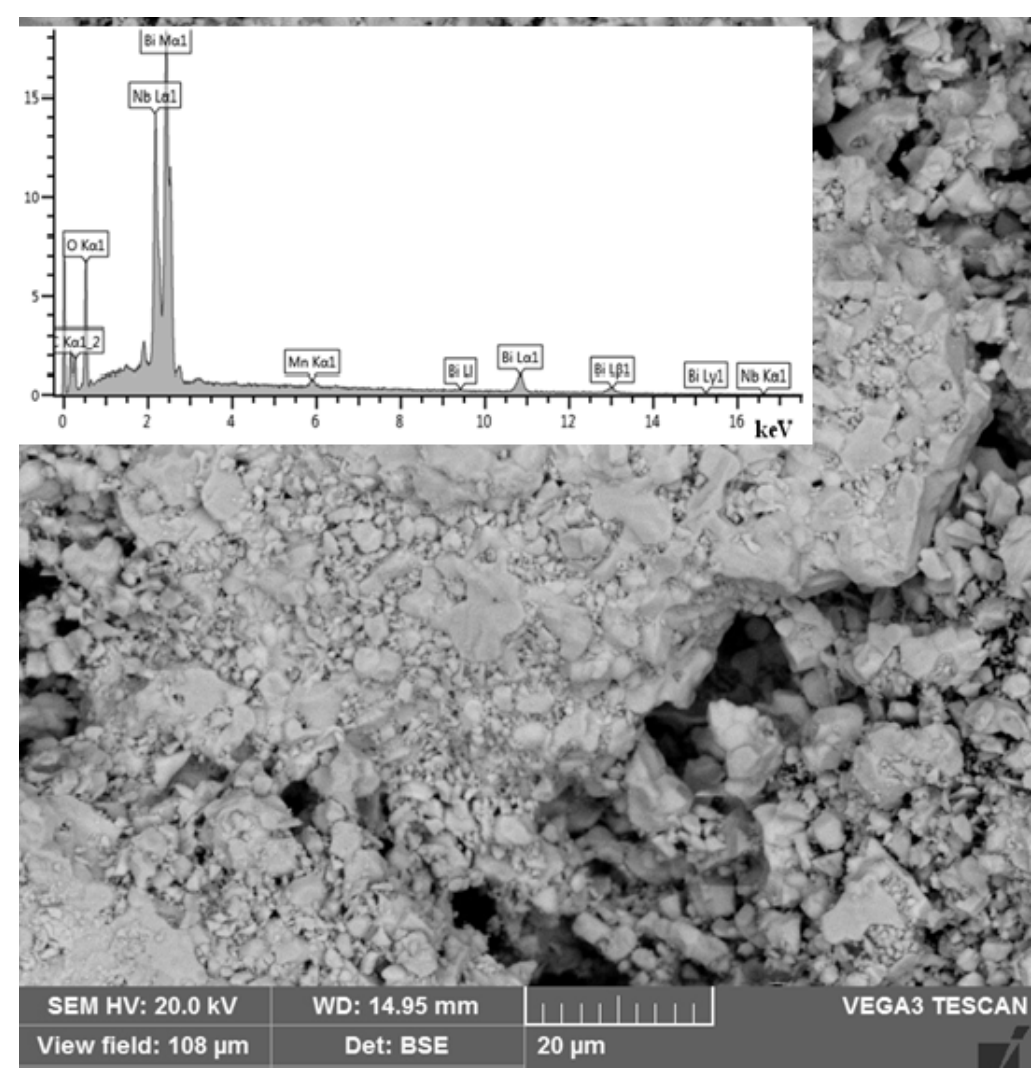

Fig. 1. Energy dispersion spectrum of $\mathrm{BiNb}_{0.94} \mathrm{Mn}_{0.06} \mathrm{O}_{4-\delta}$ and photomicrography of its surface

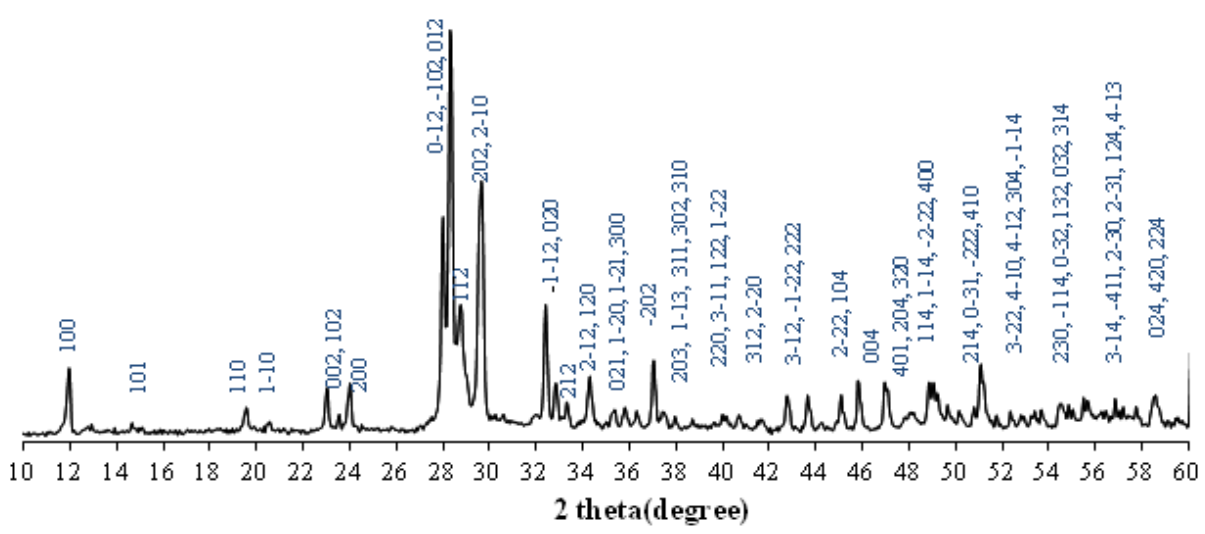

Fig. 2. X-Ray pattern for $\mathrm{BiNb}_{0.94} \mathrm{Mn}_{0.06} \mathrm{O}_{4-\delta}$

amounted to $30 \div 35$ at the change of the manganese concentration $\mathrm{x}$ in the solid solutions from 0.02 to 0.06 . The integrated intensity of the broad band with $g \sim 2.2$ varied from 60 to 80 , the additional component in the form of a wide "gap" with $g \sim 1.47$ was emerging in the spectrum as well. 
Modeling the EPR spectra of the samples of $\mathrm{BiNb}_{1-x} \mathrm{Mn}_{x} \mathrm{O}_{4-\delta}$ solid solutions of triclinic modification yielded the following results. In the general case, EPR spectra of $\mathrm{Mn}^{2+}$ ions at the $\mathrm{Nb}(\mathrm{V})$ and $\mathrm{Bi}(\mathrm{III})$ positions of bismuth orthobiobate are described by the spin Hamiltonian with triclinic symmetry:

$$
\widehat{H}=\mu B \cdot g \cdot S+S \cdot A \cdot I+\sum_{k=2,4} \sum_{q=-k}^{k} B_{k}^{q} \widehat{O}_{k}^{q} .
$$

Due to the strong variation of the crystal fields and poor resolution of components of the spectrum, the modeling of the spectra of ceramic materials is usually limited to the spin Hamiltonian of orthorhombic symmetry including only the second-order tensor of the initial splitting and the isotropic tensors of the Zeeman $(g)$ and hyperfine $\left({ }^{55} \mathrm{Mn}, A\right)$ interactions:

$$
\widehat{H}=g \cdot \mu B \cdot S+A \cdot S \cdot I+B_{2}^{0} \widehat{O}_{2}^{0}+B_{2}^{2} \widehat{O}_{2}^{2}=g \cdot \mu B \cdot S+A \cdot S \cdot I+\frac{1}{3} D \widehat{O}_{2}^{0}+E \widehat{O}_{2}^{2},
$$

where $D$ and $E$ are the parameters of the axial and rhombic fields, respectively $(E \leqslant 3 D)$.

As already noted, all spectra of the series have a low-intensity sextet structure centered in the region of $g=2.0$, which can be attributed to the central spin transition $-1 / 2-+1 / 2$ of the isolated $\mathrm{Mn}^{2+}$ ions in the weak crystal field. There were detected no lines of other transitions because of the orientational broadening and the high variation of the parameters of the crystal fields. To reproduce its shape in the model spectrum, the axial approximation was chosen $(E=0)$. The model spectrum satisfactorily approximated this component of the spectrum with the following parameters of the spin Hamiltonian: $g=2.0, D \approx 200 \cdot 10^{-4} \mathrm{~cm}^{-1}$, $\Delta D / D=0.7, A=8.6 \mathrm{mT}$, the lines of Lorentzian shape with width $\Delta B_{p p}=2.5 \mathrm{mT}$. The spectra of $\mathrm{Mn}^{2+}$ of this type were described in ceramic samples of alkali niobates: $D \approx 133 \cdot 10^{-4}$ $\mathrm{cm}^{-1}, \Delta D / D=0.45, A=8.4 \mathrm{mT}$ [7]. The assumed position of $\mathrm{Mn}^{2+}$ is $\mathrm{Nb}^{5+}$. The high variation of the crystal field parameter is associated with the large difference in the charges and the resulting stresses in the coordination polyhedra.

Sextet structure of lines $g=3.80,1.47$ can be approximated within the framework of the model of $\mathrm{Mn}^{2+}(S=5 / 2)$ in strongly rhombically distorted axial field (Fig. 2.). The modeling has shown that the best reproduction of the components of the spectrum is observed with the following parameters: $g=2.0, D=1580 \cdot 10^{-4} \mathrm{~cm}^{-1}, E=495 \cdot 10^{-4} \mathrm{~cm}^{-1}, \Delta D / D=\Delta E / E=$ $0.08(R=+1), A=8.4 \mathrm{mT}$, Lorentzian shape of the individual line with $\Delta B_{p p}=2.5 \mathrm{mT}$. In this case, the variation of the parameters of the initial splitting is small and does not exceed $10 \%$. Therefore, within the framework of this model, the positions of $\mathrm{Mn}^{2+}$ are characterized by a low statistical variability of the nearest surroundings. Their $E / D$ ratio is close to that value at maximum orthorhombic distortion equal to $1 / 3$.

We find no any literary data on EPR of $\mathrm{Mn}^{2+}$ ions in the lattice of the $\beta$-BiNbO ${ }_{4}$ crystals. Such spectra are well studied in lithium niobate crystals. It was established that $\mathrm{Mn}^{2+}$ ions in $\alpha-\mathrm{LiNbO}_{4}$ structure are localized mainly in the trigonal-symmetric octahedral positions of $\mathrm{Nb}$ with the initial splitting of $D=(720 \div 800) \cdot 10^{-4} \mathrm{~cm}^{-1}$ [7]. In our case, we revealed the twice higher $D$ value, which is close to that of $\mathrm{Fe}^{3+}$ ions in the structure of $\alpha-\mathrm{LiNbO}_{4}$ $D=(1600 \div 1800) \cdot 10^{-4} \mathrm{~cm}^{-1}$ [8]. As a rule, the magnitude of the initial $\mathrm{Fe}^{3+}$ ion splitting is twothree times higher than that value of $\mathrm{Mn}^{2+}$ ions in the same position, which was observed in $\alpha-$ $\mathrm{LiNbO}_{4}$. Our EPR measurements of $\mathrm{Fe}^{3+}$ in the $\beta-\mathrm{BiNbO}_{4}$ ceramics indicated an estimate value of $D=(1640 \div 1950) \cdot 10^{-4} \mathrm{~cm}^{-1}$, which is close to that value of $\mathrm{Mn}^{2+}\left(D=1580 \cdot 10^{-4} \mathrm{~cm}^{-1}\right)$. Such high values of $D$ of $\mathrm{Mn}^{2+}$ ions in the oxygen polyhedra are quite unexpected, the typical values are one order of magnitude lower. 


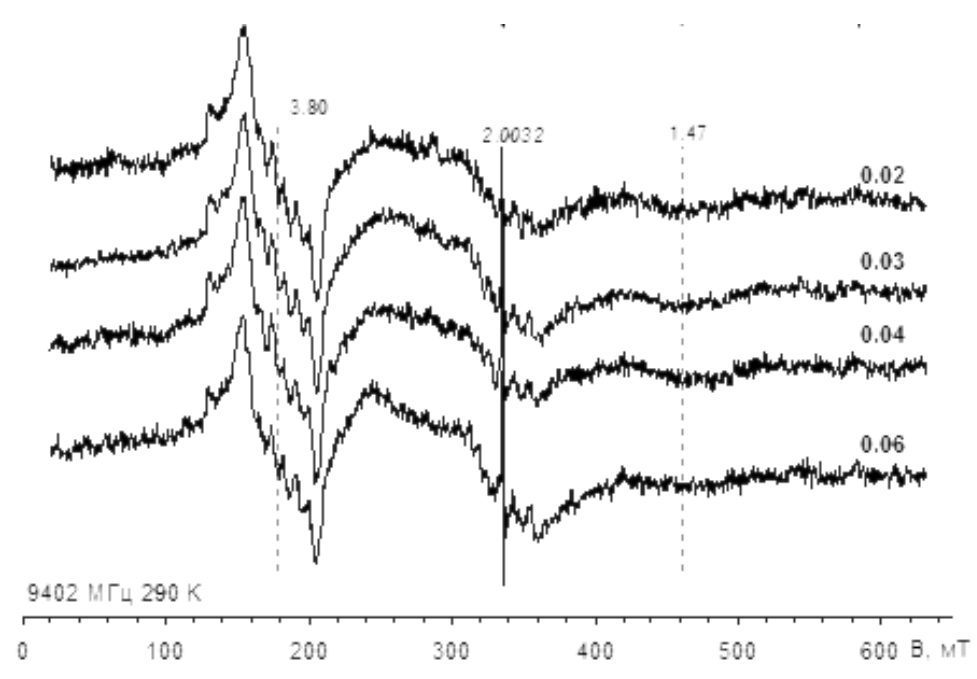

a)

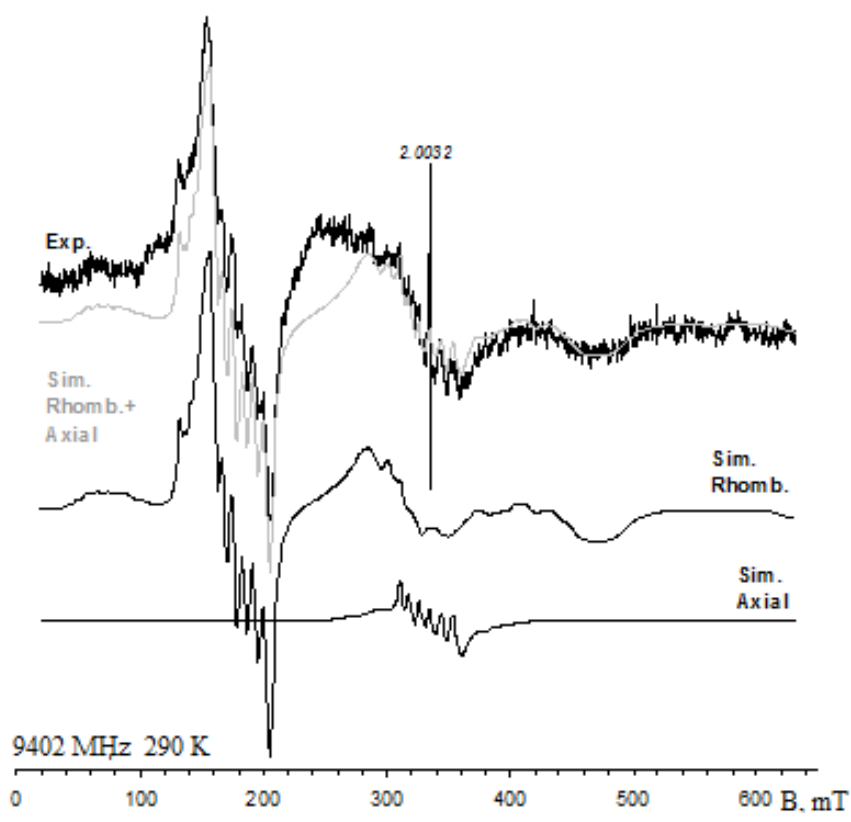

b)

Fig. 3. EPR spectra of $\mathrm{BiNb}_{1-x} \mathrm{Mn}_{x} \mathrm{O}_{4-\delta}$ solid solution samples of triclinic modification $0.02 \leqslant x \leqslant 0.06$. Reference sample line with $g=2.0032$ (a). Spectral composition of the EPR spectra of $\mathrm{BiNb}_{1-x} \mathrm{Mn}_{x} \mathrm{O}_{4-\delta}$ : Exp. is the averaged spectrum of the samples with $\mathrm{x}=0.02$, 0.03 and 0.04; Sim. Axial is the modeled spectrum with axially symmetric positions of $\mathrm{Mn}^{2+}$, $g=2.0, D=200 \cdot 10^{-4} \mathrm{~cm}^{-1}, \Delta D / D=0.7, A=8.6 \mathrm{mT}$, Lorentzian shape of the individual lines with $\Delta B_{p p}=2.5 \mathrm{mT}$; Sim. Rhomb is the modeled spectrum with rhombically distorted positions of $\mathrm{Mn}^{2+}, g=2.0, D=1580 \cdot 10^{-4} \mathrm{~cm}^{-1}, E=495 \cdot 10^{-4} \mathrm{~cm}^{-1}, \Delta D / D=\Delta E / E=0.08$ $(R=+1), A=8.4 \mathrm{mT}$, Lorentzian shape of the individual line with $\Delta B_{p p}=2.5 \mathrm{mT}$ (b)

An alternative variant of the description of the sextet structure of $g=3.80,1.47$ can be made via the model of $\mathrm{Mn}^{4+}(S=3 / 2)$. This ion in oxygen structures is characterized by high initial 
splitting and by a slightly lower value of the hyperfine interaction parameters $(7 \div 7.5 \mathrm{mT})$. The line with sextet splitting at $g=3.8$ is typical of axial complexes of $\mathrm{Mn}^{4+}$ with an initial splitting close to the value of the microwave quantum $\left(10 \mathrm{GHz}, 0.3 \mathrm{~cm}^{-1}\right)$. Such an EPR spectrum is characteristic of $\mathrm{Mn}^{4+}$ in the lattice of $\mathrm{PbTiO}_{3}\left(D=0.3166 \mathrm{~cm}^{-1}, E=0, A_{\|}=8.5\right.$, $\left.A_{\perp}=7.6 \mathrm{mT}\right)[9,10]$. The complex structure of the line with $g=3.80$ can be caused by the rhombic distortion $E \neq 0$.

Thus, absorption bands from isolated ions $\mathrm{Mn}(\mathrm{IV})$ and $\mathrm{Mn}(\mathrm{II})$ in crystal fields of various symmetry and manganese atoms clusters were registered in the EPR spectra. The increase in manganese concentration in the solid solutions results in the increase of a portion of manganese(III) atoms which are not seen in the EPR spectrum at room temperature.

\section{Conclusions}

The sextet structure of $\mathrm{Mn}$ (II) ions with $8.4 \mathrm{mT}$ splitting and features at $g=3.80$ and 1.47 , and a broad diffuse band with $g \sim 2.2$ having a sextet with $8 \div 9 \mathrm{mT}$ splitting and $g=2.0$ against its background have been recorded in the EPR spectra. The broad band with $g \sim 2.2$ can be referred to managanese(IV) ions or managanese atom clusters. The sextet structure of the bands with $g=3.80$ and 1.47 can be referred to $\mathrm{Mn}^{2+}$ ions in a rhombically-distorted axial field with the ratio of axial and rhombic field parameters $E / D$ close to $1 / 3$. This can be explained by a strong distortion of nonequivalent octahedral niobium sites in the high-temperature phase of bismuth orthoniobate.

\section{References}

[1] V.I.Popolitov, A.N.Lobachev, V.F.Peskin, Antiferroelectrics, ferroelectrics and pyroelectrics of a stibiotantalite structure, Ferroelectrics, 40(1982), 9-16.

[2] S.S.Dunkle, K.S.Suslick, Photodegradation of $\mathrm{BiNbO}_{4}$ Powder during Photocatalytic Reactions, J. Phys. Chem. C., 113(2009), 10341-10345.

[3] H.Kagata, T.Inoue, J.Kato, I.Kameyama, Low-Fire Bismuth-Based Dielectric Ceramics for Microwave Use, Jpn. J. Appl. Phys. Part 1., 31(1992), 3152-3155.

[4] K.Sang, Y.Kyung, Characteristics of tapped microstrip bandpass filter in $\mathrm{BiNbO}_{4}$ ceramics, J. Mater. Sci. Mater. in Electronics, 9(1998), 351-356.

[5] B.Aurivillius, X-ray investigations on $\mathrm{BiNbO}_{4}, \mathrm{BiTaO}_{4}$ and $\mathrm{BiSbO}_{4}$, Ark Kemi, 3(1951), 153-161.

[6] L.G.Akselrud, Yu.N.Grin, P.Yu.Zavalij, et al., CSD-universal program package for single crystal or powder structure data treatment, Thes. Rep. XII Eur. Crystallographic. Meet., 3(1985), 155.

[7] T.H.Yeom, S.H.Choh, Y.M.Chang, C.Rudowicz, EPR Study of Low Symmetry $\mathrm{Mn}^{2+}$ Centers in $\mathrm{LiNbO}_{3}$, Phys. St. Sol., 185(1994), 417-428.

[8] T.H.Yeom, Y.M.Chang, S.H.Choh, C.Rudowicz, Experimental and Theoretical Investigation of Spin-Hamiltonian Parameters for the Low Symmetry $\mathrm{Fe}^{3+}$ Centre in $\mathrm{LiNbO}_{3}$, Phys. St. Sol., 185(1994), 409-415. 
[9] D.Hennings, H.Pomplun, Evaluation of Lattice Site and Valence of Mn and Fe in Polycrystalline $\mathrm{PbTiO}_{3}$ by Electron Spin Resonance and Thermogravimetry, J. Am. Ceram. Soc., $\mathbf{5 7}(1973), 527-530$.

[10] D.J.Keeble, Z.Li, E.H.Poindexter, Electron paramagnetic resonance of $\mathrm{Mn}^{4+}$ in $\mathrm{PbTiO}_{3}$, J. Phys.: Condens. Matter., 7(1995), 6327-6333.

\title{
Моделирование спектров ЭПР $\mathrm{BiNb}_{1-x} \mathrm{Mn}_{x} \mathrm{O}_{4-\delta}$ триклинной модификации.
}

\author{
Владимир П. Лютоев \\ Институт геологии Коми НЦ УрО РАН \\ Первомайская, 54, Сыктывкар, 167000 \\ Россия \\ Надежда А. Жук \\ Сыктывкарский государственный университет им. Питирима Сорокина \\ Октябрьский, 55, Сыктывкар, 167001 \\ Россия \\ Борис А. Макеев \\ Институт геологии Коми НЦ УрО РАН \\ Первомайская, 54, Сыктывкар, 167000 \\ Россия \\ Владимир А. Белый \\ Институт химии Коми НЦ УрО РАН \\ Первомайская, 48, Сыктывкар, 167982 \\ Россия \\ Дмитрий С. Безносиков \\ Сыктывкарский государственный университет им. Питирима Сорокина \\ Октябрьский, 55, Сыктывкар, 167001 \\ Россия
}

$\overline{\text { Исследован ЭПР в твердых растворах } \mathrm{BiNb}_{1-x} \mathrm{Mn}_{x} \mathrm{O}_{4-\delta} \text { триклинной модификации. В спектрах }}$ ЭПР зарегистрированы секстетнал структура ионов $M n(I I)$ с расщеплением 8.4 мТ с особенностями в области $g=3.80$ и 1.47 и широкая размытая полоса с $g \approx 2.2$, на фоне которой проявляется секстет с расщеплением $8 \div 9$ мT и $g=2.0$. Как показало моделирование, наилучшим образом компоненты спектра воспроизводятся при следующих параметрах спин-Гамильтониана: $g=2.0, D=1580 \cdot 10^{-4} \mathrm{~cm}^{-1}, E=495 \cdot 10^{-4} \mathrm{~cm}^{-1}, \Delta D / D=\Delta E / E=0.08, A=8.4$ мT, Лоренцева форма индивидуальной линии с $\Delta B_{p p}=2.5$ мT.

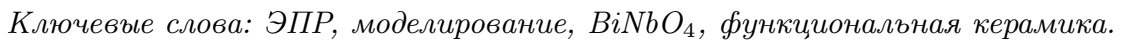

